American Journal of Animal and Veterinary Sciences 3 (1): 36-39, 2008

ISSN 1557-4555

(C) 2008 Science Publications

\title{
Prevalence and Distribution of Mastitis Pathogens and their Resistance Against Antimicrobial Agents in Dairy Cows in Jordan
}

\author{
${ }^{1}$ Azmi D. Hawari and ${ }^{2}$ Fawzi Al-Dabbas \\ ${ }^{1}$ Department of Nutrition and Food Processing, Faculty of Agricultural Technology, \\ Al-Balqa Applied University, Al-Salt, Jordan \\ ${ }^{2}$ Al-Salt University College, Al-Balqa Applied University, Alsalt, Jordan
}

\begin{abstract}
The primary objective of this study was to determine the aetiology of bovine mastitis in ten herds of Holstein Friesian cow in Jordan, the prevalence of mastitis pathogens in dairy cows and their resistance to selected antimicrobial agents. Milk samples were collected from 220 lactating cows to determine the clinical and subclinical mastitis by white side test and confirmed by cultural tests. It was found that 138 quarters $15.7 \%$ had been diagnosed as clinical mastitis with definite gross pathological lesions and change in udder secretion, in addition to that 276 quarters $31.4 \%$ showed subclinical mastitis. The incidence of mastitis was found to be increased in older cows. Staphylococcus aurous was considered to be the most common cause of both clinical and subclinical mastitis and followed by coli forms, streptococcus spp., corynebacterium spp., proteus spp. and pseudomonas spp. Sensitivity tests was applied to different isolated strains using tertracycline, ampicillin, neomycin, erythromycin, penicillin $\mathrm{G}$ and sulphamethoxazol trimethoprim.
\end{abstract}

Key words: Cattle-microbiological diseases, mastitis, Jordan

\section{INTRODUCTION}

Mastitis is considered one of the most important dairy cattle diseases and is one of the major causes of antibiotics use in dairy cows ${ }^{[1,2]}$. Over 135 different microorganisms have been isolated from bovine intramammary infection, but the majority of infections are caused by staphylococci, streptococci and gramnegative bacteria ${ }^{[3]}$. Where is staphylococcus aureus was isolated from $18 \%$ of the culture positive quarter ${ }^{[4]}$.

Mastitis known to be a complex and costly disease of dairy cows that results from the interaction of the cow and the environment including the milking machine and the microorganisms ${ }^{[5-7]}$, although stress and physical injuries may cause inflammation of mammary glands, infection by invading bacteria or other microorganisms (fungi, yeast and possibly viruses) is the primary cause of mastitis ${ }^{[8,9]}$.

Jordan has experienced a rapid population growth over the last three decades and an increased demand for milk and dairy products. Mastitis is considered to be the most frequent disease of dairy cattle in Jordan and has received more veterinary attention as a disease of cattle and as a serious economic problem ${ }^{[10,11]}$.

Mastitis is produced by a variety of pathogenic microorganisms. Cows and herds vary in susceptibility and extent, type and duration of infection, although some of mammary pathogens can be isolated from the environment of the cow, manure and bedding, water supplies, soil and inadequately cleaned milking machines ${ }^{[12,13]}$, thus new infection can be reduced by applying rigid herd management practices ${ }^{[14]}$. Measures to control mastitis such as improved milking hygiene have reduced streptococcus agalactia ${ }^{[15-17]}$. The incidence of the disease was influenced with the lactation and age of the animal; higher infection were reported in older cows ${ }^{[18,19]}$.

The aim of this paper was to determine the prevalence of mastitis pathogens in clinically and subclinically of dairy cows, a further objective was to determine the susceptibility of these bacteria to 6 antimicrobial agents that are or have been commonly used in dairy cows in Jordan.

\section{MATERIALS AND METHODS}

Milk samples were collected from 220 Holstein Friesian cows in 10 farms in Thuleil area, full history was reported for cows in all farms. The health status of the udder and the age of the cows were recorded. Prior to sampling the udder was washed and dried and the teat was disinfected. All milk samples were collected

Corresponding Author: Azmi Hawari, Department of Nutrition and Food Processing, Faculty of Agricultural Technology, AL-Balqa Applied University, P.O. Box 7027, AL-Salt, Jordan 
all over the year 2006 under aseptic condition. About $15 \mathrm{~mL}$ of the foremilk were discarded and the next fifteen $\mathrm{mL}$ were collected into screw-capped bottles and transferred in ice boxes to the laboratory. All samples were stored at $4^{\circ} \mathrm{C}$ from the time of collection until examination within 3-4 h.

All samples were centrifuged for $15 \mathrm{~min}$ at $3000 \mathrm{rpm}$ and a loopfull was taken from sediment and inoculated separately on each of the following media, 5\% sheep blood agar, Edwards and Mac Conkey's agar. The inoculated plates were then incubated at $37^{\circ} \mathrm{C}$ for 24, 48 and 72 h. From growing colonies smears were made and stained with Grams stain. In case of Streptococcus strains it was identified by the morphological character on blood agar and specific Edwards media. For identification of isolated Staphylococcus strains by colonial appearance on blood agar, pigments, haemolysis and for pathogenicity by using tube method of coagulase test. Coliforms, Proteus spp., Corynebacterium spp., pseudomonas spp. and the other Gram negative bacilli were identified by morphological character on sheep blood agar and by biochemical reaction when necessary.

Sensitivity tests were carried out on the isolates by using sensitest agar (oxoid) and susceptibility discs (oxoid). The discs used contained Neomycin $30 \mu \mathrm{g}$, Ampicillin $10 \mu \mathrm{g}$, Tetracycline $30 \mu \mathrm{g}$, Erythromycin $15 \mu \mathrm{g}$, Penicillin G $10 \mathrm{IU}$, Sulthamethoxazole Trimethoprim (SXT) $25 \mu \mathrm{g}$.

\section{RESULTS AND DISCUSSION}

The incidence of clinical mastitis in udder quarters of Holstein Friesian cows in ten farms was found to be $15.7 \%$ Table 1. This is a little higher than that reported before in Holstein Friesian cows in Egypt $12.08 \%{ }^{[20]}$. The incidence of subclinical mastitis, however, averaged $31.4 \%$ in this investigation as based on udder quarters (Table 2).

It was evident in this study that mastitis was increased with advanced age. It is noticed in some herds the incidence of clinical and subclinical mastitis was increased with the sixth years old Table 3, Fig. 1.

The relative frequency of different types of microorganisms in this study revealed that staphylococcus aureus, Coliforms and streptococcus spp. were the chief aetiological agents responsible for both clinical and subclinical mastitis Table 4. These results agree with those presented by others ${ }^{[3,10,21]}$.

In clinical mastitis the incidence of Coliform $26.1 \%$, Streptococcus spp $8.7 \%$, Staphylococcus aureus 40.6\%, Proteus spp. 1.4\%, Corynebacterium spp. 5.8\% Pseudomonas spp. $4.3 \%$, mixed (coryne, strept, staph
Table 1: Incidence of clinical mastitis quarters

\begin{tabular}{|c|c|c|c|c|}
\hline $\begin{array}{l}\text { No. of } \\
\text { animal } \\
\text { examined }\end{array}$ & $\begin{array}{l}\text { No. of } \\
\text { animal } \\
\text { examined }\end{array}$ & $\begin{array}{l}\text { Clinically } \\
\text { mastitis } \\
\text { quarters }\end{array}$ & $(\%)$ & $\begin{array}{l}\text { Apparently } \\
\text { normal } \\
\text { quarter }\end{array}$ \\
\hline 220 & 880 & 138 & 15.7 & 642 \\
\hline
\end{tabular}

Table 2: Incidence of sub clinical mastitis

\begin{tabular}{|c|c|c|c|c|c|c|}
\hline \multirow{2}{*}{$\begin{array}{l}\text { No. of } \\
\text { examined } \\
\text { quarters }\end{array}$} & \multicolumn{3}{|c|}{ Scores of white side test } & \multirow[b]{2}{*}{ Total } & \multirow[b]{2}{*}{$(\%)$} & \multirow{2}{*}{$\begin{array}{l}\text { Normal } \\
\text { quarters }\end{array}$} \\
\hline & + & ++ & +++ & & & \\
\hline 880 & 72 & 94 & 110 & 276 & 31.4 & 604 \\
\hline
\end{tabular}

Table 3: Incidence of clinical and sub clinical mastitis in relation to the age

\begin{tabular}{lllllll}
\hline $\begin{array}{l}\text { Age of the } \\
\text { cow (years) }\end{array}$ & 3 & 4 & 5 & 6 & 7 & Total \\
\hline $\begin{array}{l}\text { Diseased } \\
\text { quarters }\end{array}$ & 61 & 70 & 73 & 106 & 104 & 414 \\
$\%$ & 14.7 & 16.9 & 17.7 & 25.6 & 25.1 & 100 \\
\hline
\end{tabular}

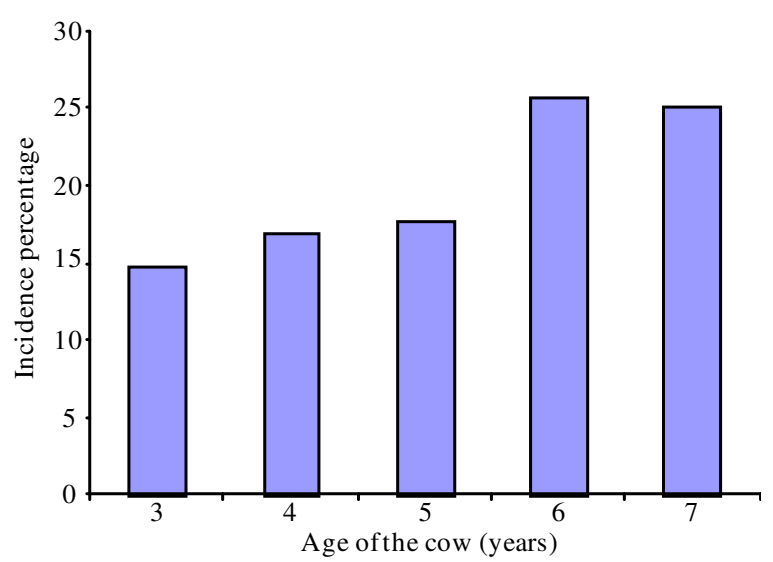

Fig. 1: Incidence of clinical and subclinical mastitis in relation to the age

and Coliforms) $7.3 \%$ and others $5.8 \%$. While in subclinical mastitis Coliforms were $31.9 \%$, Streptococcus spp. 7.2\%, Staphylococcus aureus 42.7\%, Proteus spp. $2.2 \%$, Corynebacterium spp. $2.9 \%$, mixed and others $13.1 \%$. National cross-sectional study of mastitis in dairy cattle in Jordan ${ }^{[22]}$, it was reported that the most estimates of prevalence of bacterial pathogens intramammary infections were: coagulase negative Staphylococci $16.04 \%$, Staph. aureus $9.41 \%$, Klebsiella spp. $6.17 \%$, Corynebacterium bovis $5.35 \%$ and Brucella melitensis $4.52 \%$.In U.K. the distribution of the 1457 clinical cases according to the result of the culture was E-coli $32 \%$, strept uberis $23 \%$ staph $7 \%$, Corynpyogens $1 \%$ mixed $10 \%$ and others $24 \%{ }^{[23]}$ while In Germany the mastitis pathogens were isolated from $26.4 \%$ of the milk samples and the major pathogens, staph. aureus $5.7 \%$ and streptococcus uberis $1 \%$ had the highest prevalence, at the same time streptococcus 
American J. Animal \& Vet. Sci., 3 (1): 36-39, 2008

Table 4: Incidence of various organisms in clinical and sub clinical mastitis

\begin{tabular}{|c|c|c|c|c|c|c|c|c|c|}
\hline \multirow[b]{2}{*}{ Mastitis } & \multicolumn{6}{|c|}{ No. of quarters infected by each type of bacteria } & \multirow[b]{2}{*}{ Mixed $_{1}$} & \multirow[b]{2}{*}{ Others $_{2}$} & \multirow[b]{2}{*}{ Total } \\
\hline & Coliforms & Strept. & Staphylococcus aurous & Proteus spp. & Corynebacterium spp. & Pseudomonas spp. & & & \\
\hline \multirow[t]{2}{*}{ Clinical No } & 36.0 & 12.0 & 56.0 & 2.0 & 8.0 & 6.0 & 10.0 & 8.0 & 138 \\
\hline & $26.1 \%$ & 8.7 & 40.6 & 1.4 & 5.8 & 4.3 & 7.3 & 5.8 & \\
\hline Subclinical & 88.0 & 20.0 & 118.0 & 6.0 & 8.0 & 00 & 30.0 & 6.0 & 276 \\
\hline No & $31.9 \%$ & 7.2 & 42.7 & 2.2 & 2.9 & 00 & 10.9 & 2.2 & \\
\hline
\end{tabular}

Mixed = Corynebacterium, strept , Staph . and coliform

Others $=$ Sterile and unsatisfactory samples

Table 5: Percentage for the sensitivity of bacteria that isolated from milking cows to different antibiotics

\begin{tabular}{|c|c|c|c|c|c|c|c|c|}
\hline Antibiotics & Disc potency & Coliforms & Strept spp. & Staph aureus & Proteus spp. & Corynebacterium spp. & Pseudomonas spp. & Total $(\%)$ \\
\hline Tetracycline & $30 \mathrm{ug}$ & 34.5 & 75 & 71.8 & 75 & 87.5 & 100 & 64 \\
\hline Ampicillin & $10 \mathrm{ug}$ & 9.7 & 62.5 & 80.5 & 0 & 87.5 & 0 & 52.8 \\
\hline Neomycin & $30 \mathrm{ug}$ & 17.7 & 12.5 & 27.6 & 12.8 & 12.5 & 0 & 21.4 \\
\hline Erythromycin & $15 \mathrm{ug}$ & 24.2 & 87.5 & 35.6 & 50 & 62.5 & 0 & 36 \\
\hline Penicillin G & $10 \mathrm{Iu}$ & 23.3 & 56.2 & 69 & 0 & 81.25 & 0 & 54 \\
\hline $\begin{array}{l}\text { Sulphamethoxazo } \\
\text { Trimethoprim } \\
\text { (SXT) }\end{array}$ & $125 \mathrm{ug}$ & 74.2 & 62.5 & 74.7 & 100 & 75 & 100 & 75 \\
\hline
\end{tabular}

Table 6: Analysis of variance for six antibiotics and six bacteria

\begin{tabular}{llrrr}
\hline Source of variation & DF & \multicolumn{1}{c}{ SS } & \multicolumn{1}{l}{ MSS } & F-ratio \\
\hline Antibiotics & 5 & 10675.945 & 2135.189 & 4.635 \\
Bacteria & 5 & 3465.065 & 693.013 & 1.500 \\
Error & 25 & 11514.307 & 460.572 & \\
Total & 35 & 25655.317 & & \\
\hline
\end{tabular}

agalactia was isolated in samples from $29 \%$ of the herds ${ }^{[19]}$. Bacteriological data from herds surveys by the Massachusetts Mastitis Loboratory were analyzed and showed that Staph. aureus and coliforms were the predominant organisms isolated from Holstein Friesian cow mastitis a result which is similar to our result $^{[24]}$.

It would be of interest to note that in Sudan ${ }^{[25]}$ the organisms isolated in clinical and subclinical mastitis in Zebu cattle were staph spp.50 and 68.7\%. Strept spp. 15.3 and $12.6 \%$, Coryn. spp. 11 and $00 \%$ coliforms 11 and $4.8 \%$ and mixed 10.2 and $13 \%$. In Jordan it was reported that the most common organisms isolated from clinical and subclinical cases were staph. spp. $30 \%{ }^{[11]}$.

There results of sensitivity tests of the organisms isolated to antibiotics Table 5 shown that $75 \%$ of strains were sensitive to Sulphamethaxazol Trimethoprim, $64 \%$ to Tetracycline, $54 \%$ to Peniciilin G, $52.8 \%$ to Ampicillin, $36 \%$ to Erythromycin and $21.4 \%$ to Neomycin.

Statistical analysis: The analysis of variance for antibiotics sensitivity showed that there are differences between antibiotics treatment at $1 \%$ level of significant (Table 6). At the same time there are no significant differences between isolated organisms.

\section{CONCLUSION}

In conclusion, more efforts are needed to improve the general udder health in dairy herds as approximately $47.1 \%$ of the cows had at least one infected quarter (clinically or sub-clinically), so the recommended preventive and control measures against mastitis should include application of good sanitary and hygienic measures. In addition to that regular monitoring of the prevalence and the distribution of mastitis-causing pathogens provides, however, valuable knowledge about the effectiveness of proposed control strategies and helps in prioritizing specific mastitis control efforts.

\section{ACKNOWLEDGEMENT}

We thank Dhia Hassawi for his help in the statistical analysis of the results.

\section{REFERENCES}

1. Mitchell, J.M., M.W. Griffiths, S.A. McEwen, W.B. Menab and A.J. Yee, 1998. Antimicrobial drug residues in milk and meat: Causes, concerns, prevalence, regulations, tests and test performance. J. Food Protect. 61: 742-756. http://www.ingentaconnect.com/content/iafp/jfp/19 98/00000061/00000006/art00020.

2. DANMAP (Danish Integrated Antimicrobial Resistance monitoring and Research Programme.)2003. Use of antimicrobial agents and occurrence and antimicrobial resistance in bacteria from food animals, foods and humans in Denmark 2003. DANMAP, Soborg, Denmark. http:// www.danmap.org/pdfFiles/Danmap_2003.pdf. 
3. Bradley, A.J., 2002. Veterinary drug usage and antimicrobial resistance in bacteria of animal origin. Basic Clin. Pharm. Toxicol., 96: 71-281. DOI: 10.1111/j.1742-7843.2005.pto960401.x.

4. Sofie Piepers, Luc De Meulemeester, Aart de Kruif, Greet Opsomer, Herman w Barkema and Sarne De Vliegher, 2007. Prevalence and distribution of mastitis pathogens in subclinically infected dairy cows in Flanders, Belgium. J. Dairy Res., 74: 478-483. DOI: 10.1017/ 50022029907002840.

5. Brown, R.W., R.J. Eberhart, J.S. Mc Donald, R.P. Natzke, D.S. Postle and O.W. Schalm, 1972. Supplement to Current Concepts of Bovine Mastitis. National Mastitis Council, Washongton, DC.

6. Blossor, T.H. 1979. Economic losses from and the national research program on mastitis in the United States. J. Dairy Sci., 62: 119-127. http://jds.fass.org/cgi/content/abstract/62/1/119.

7. Radostitis, O.M., D.C. Blood and C.C. Gay, 1994. Veterenary Medicine. 8th Edn. Billiere Tindall, London, pp: 563-614.

8. Wattiaux, M.A., 1999. Mastitis: The Disease and its Transmission. In: Dairy Essentials. Chapter 23. Babcock Institute for International Dairy Research and Development. University of WisconsinMadison, pp: 89-92.

9. Ruegg, P.L., 2001. Mastitis Control. In: Dairy Updates: Milking and Milk Quality No. 405. The Babcock Institute, University of Wisconsin, pp: 10.

10. Lafi, S.Q. and N.Q. Hailat, 1998. Incidence and antibiotic sensitivity of bacteria causing bovine and ovine clinical mastitis in Jordan. Pak. Vet. J., 18: 88-94. http://www.parc.gov.pk/data/CatPak/ cataction.asp?NAV $=16 \&$ Title $=$ aus $\&$ Author $=\&$ corp orateAuthor $=\&$ Publisher $=\&$ PublicationDate $=\&$ sub jectheadings $=$.

11. Lafi, S.Q., O.F. Al-Rawashdeh, K.L. Ereifej and N.Q. Hailat, 1994. Incidence of clinical mastitis and prevalence of subclinical udder infection in Jordan. Dairy Cattle Prev. Vet. Med., 18: 89-98. http://www.fao.org/agris/search/display.do?f=./199 4/v2011/NL9401714.xml;NL9401714.

12. Jain, N.C., 1979. Dommon pathogens and factors in infection and mastitis. J. Dairy Sci ., 62: 128-134. http://jds.fass.org/cgi/content/ abstract/62/1/128.

13. Philpot, W.N., 1979. Control of mastitis by hygiene and therapy. J. Dairy Sci., 62 : 168-176. http://www.ncbi.nlm.nih.gov/pubmed/379060.

14. Schalm, O.W., E.J. Carroll and N.C. Jain, 1971. Bovine Mastitis, Lea and Febiger. Pheladelphia.
15. Mylllys, V., K. Asplund, E. Brofeld, V. Hirvela-Koski, T. Homkanen-Buzalski, J. Junttila, L. Kulkas, O. Myllykan, M. Niskanen, H. Saloniemi, M. Sandholm and T. Saranpaa, 1998. Bovine mastitis in Finland in 1988 and 1995change in prevalence and antimicrobial resistance. Acta Vet. Scand, 39: 119-126. http://www.ncbi.nlm.nih.gov/pubmed/9592952.

16. Makovec, J.A. and P.L. Ruegg, 2003a. Results of milk samples submitted for microbiological examination in Wisconsin from 1994-2001. J. Dairy Sci., 86: 3466-3472. http://jds.fass.org/ cgi/content/full/86/11/3466.

17. Pitkala, A., M. Haveri, S. Pyorala, V. Myllys and T. Honkanen-Buzalski, S2004. Bovine mastitis in Finland 2001-prevalance, distribution of bacteria and antimicrobial resistance. J. Dairy Sci., 87: 2433-2441. http://jds.fass.org/cgi/content/ abstract/87/8/2433.

18. Sharma, R.M. and R.A. Pacher, 1980. Occurrence and ecologic features of Streptococcus uberis in the dairy cow. Am. J. Vet., 31: 1197. http://www.ncbi.nlm.nih.gov/pubmed/4915060.

19. Tenhagen, B.A., G. Koster, J. Wallman and W. Heuwieser, 2006. Prevalence of mastitis pathogens and their resistance against antimicrobial agents in dairy cows in Brandenburg, Germany. J. Dairy Sci., 89: 2542-2551. http://www.dairyscience.org/cgi/reprint/89/7/2542.

20. Abd El-Moneim, M., 1979 Incidence of mastitis in a village of Sharkia province and its treatment. M.V. Sc. Thesis, Cairo University.

21. Smith, M.C., 1990. Exclusion of infectious diseases from sheep and goat farms. Vet. Clin. North Am. Food Anim. Pract. (USA), 6: 705-720. http://www.ncbi. nlm.nih.gov/sites/entrez.

22. Lafi, S., O. Al-Rawashdeh, T. Na'Was and N. Hailat, 1994. National cross-sectional study of mastitis in dairy cattle in Jordan. Trop. Anim. Health Prod. 26: 168-174. DOI: 10.1007/BF02241077.

23. Fauli, W.B., J.R. Walton, A.J. Bramly and J.W. Huges, 1983. Mastitis in a large Zero-grazed dairy herd. Vet. Rec., 29: 415-420. http://veterinaryrecord.bvapublications.com/cgi/co ntent/abstract/113/18/415.

24. Oliver, S.P. and A.B. Mitchell, 1984. Prevalence of mastitis pathogens in herds. Participating in a mastitis control program. J. Dairy Sci., 67: 2436-2440. http://jds.fass.org/cgi/ content/abstract/67/10/2436?ck=nck.

25. Bagadi, H.O., 1970 The aetiology of bovine mastitis in three areas in Sudan. Trop. Anim. Health Prod., 2: 28-34. DOI: 10.1007/BF02359326. 